\title{
Analysis of the issue of virtual economic globalization and national economic security
}

\author{
Yun Huang ${ }^{1, ~ a, ~ X i ~ Z h a o ~}{ }^{1, b}$ and Anshu Jiang ${ }^{1, c}$ \\ ${ }^{1}$ Department of Finance and Economics, Fujian Normal University, Fujian, 350117, China \\ a1091186727@qq.com, b2011237525@qq.com, '326289449@qq.com
}

Keywords: globalization of virtual economy; national economic security; analysis

Abstract. The development of virtual economy in recent years has resulted in widening gap between the output of real economy and virtual economy. The development degree of virtual economy has risen to be measure of national competitiveness in the international market. Globalization of virtual economy has brought new challenges to various countries and the whole world. In China, a large number of financial markets and other primary industries of virtual economy are popping up, adding to ferocity of industrial competition. In the international arena, virtual economic output has been a gauge of a country' s international position. Against the backdrop, it is of vital importance to study the issue of national economic security.

\section{Introduction}

Economic security has been a top priority during a country's economic development process. The Theory of Virtual Economy emphasizes the essence of economic globalization is globalization of virtual economy. Therefore, China's national economic security prevention and control system should be enhanced to avoid risks of virtual economy. Development of virtual economy has posed a great threat to national economic security. Thus, this paper analyzes the issue of virtual economic globalization and national economic security from the perspective of demonstrations of virtual economic globalization and development status of national virtual economy.

\section{Development status of national virtual economic development}

Before analysis of China's domestic virtual economic development status, the concept of virtual economy should first be clarified. Literally, virtual economy means invisible economy, which is essentially different from real economy in terms of operation modes and economic subjects. The virtual economic system mainly consists of the bond market, the stock market, the foreign exchange market and the real estate market. The market value of virtual economy refers to the sum of market value generated by virtual economy. Below is the market value of China's virtual economy from 2000 to 2005, which is used to show leapfrog development of China's virtual economy. See Fig.1 below:

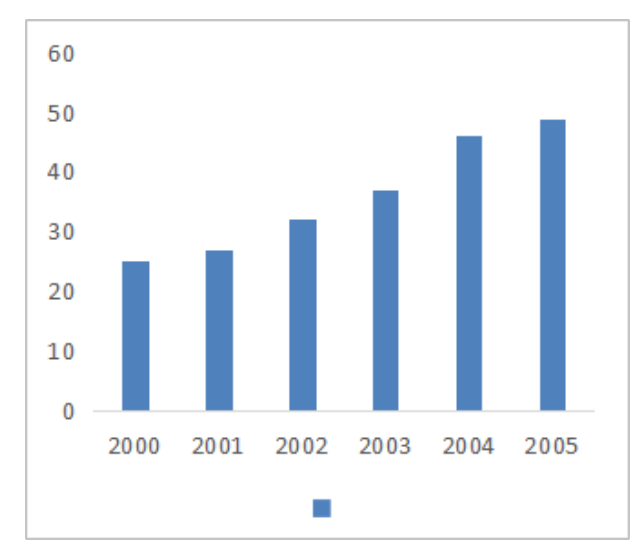

Fig. 1 Market value of China’s virtual economy (1997-2005; unit: trillion RMB) 
Data in Fig.1 come from the website of the China Securities Regulatory Commission, ChinaBond.com.cn, China's statistical yearbooks, etc. The above data show that the market value of China's virtual economy was rising steadily. [1]

Since the big data of virtual economy have not yet been statistically analyzed, development status of China's virtual economy can be shown in Table 1 according to changes of the market value increase proportion of various constituents of virtual economy.

Table 1 Market value change proportion of major parts of virtual economy from 2013 to 2015

\begin{tabular}{llll}
\hline Year & $\begin{array}{l}\text { Stock } \\
(\%)\end{array}$ & $\begin{array}{l}\text { Foreign exchange } \\
(\%)\end{array}$ & $\begin{array}{l}\text { Bond } \\
(\%)\end{array}$ \\
\hline 2013 & 3.15 & 1.3 & 3.7 \\
2014 & 7.36 & 6.72 & 5.1 \\
2015 & 9.13 & 9.18 & 11.8 \\
\hline
\end{tabular}

Based on the above analysis, it can be seen that China's virtual economy keeps development, and that the economic profits brought by it have far overtaken those brought by real economy in some sense.

\section{Demonstrations of virtual economic globalization}

Globalization of virtual economy is globalization of various constituents of virtual economy. To be specific, globalization of virtual economy is reflected as globalization of finance, globalization of real estate virtual assets and globalization of the virtual economic system.

A. Globalization of the financial market

Financial market a huge economic concept with multiple branches, including the stock market, the bond market and the futures market. Every branch has been developed into an independent system. Therefore, globalization of the financial market is a major part of virtual economic globalization. [2]

Financial globalization is demonstrated in the following aspects:

First, globalization of the capital flow direction and flow. Along with the development of the financial industry, capitals can flow into and out from a country. Either in developed countries or developing countries, capital flow is faced with many uncertain factors. It is no longer restricted to country-to-country circulation, but has entered into global circulation.

Second, asset-backed securitization (ABS), which gradually takes shape during the globalization process. To some small-and medium-sized enterprises, ABS is a financing channel, and even the only financing means due to their development limits. ABS means that certain asset or certain asset portfolio adopts the asset operation mode of securities. During its development process, the focus is directly on the international market. Various institutions purposely select asset portfolios which can maximize their corporate profits. All these activities contribute to frequency of the international asset flow.

At last, increasing consistency of economic systems against the backdrop of financial globalization. Differences between financial institutions and traditional banks have been blurred during financial globalization. All-around and integrated modes have gradually displayed themselves in these financial institutions. Major national supervision objects have shifted to financial institutions, which has shown consistency either in terms of legal formulation or in terms of industrial restrictions and standards. 
B. Globalization of the real estate virtual assets

The real estate subprime crisis is an important cause of the economic crisis. During economic depressions, if the real estate economy is also on the downward, it might seriously jeopardize economy.

Internationalized investment of the real estate market has been a major demonstration of globalization of real estate virtual assets. With the advent of the new era, rapid development of the information society and emergence of various communications techniques, including the Internet, have increased frequency of information exchange among countries. As the international capital flow channels diversify, the capital flow has avoided many complex formalities. Convenient international capital flows have provided the feasible prerequisite for the real estate investment. [3]

As an immovable property, real estate cannot yet achieve international development under the traditional economic development trend. However, along with internationalization of various markets and derivation of more convenient financial tools, the real estate investment has found its objective and direction, thus driving the joint development of the global real estate industry.

Globalization of the virtual economic system

The virtual economic system is a whole made up of different individual markets. Based on globalization of various markets, globalization of the virtual economic system has been an irresistible trend. Different industries are connected in the international arena. "Capitals" should take the credit for it. Since the capital flow and operation mode has been international, and dominated mutual exchange of various markets in various markets, integral globalization is irresistible.

\section{Influence of virtual economy on economic stability and economic security and countermeasures therefor}

3.1 Influence of the virtual economy on economic stability and security

Virtual economy is a system in itself. Various constituents within it have certain influence on economic security and stability. The outbreak of the economic crisis has been a good lesson for the country and the government, that is, to enhance supervision intensity and prevent the financial market from being manipulated through various means, thus upsetting the stability of the national economic structure.

The competition in the financial industry of a country can influence that in the international level. As science and technology, and network keeps on developing, the financial market is faced with certain risks. Either at home or abroad, disguised manipulation of the financial market, rule-breaking establishment of markets to get people's property and phenomena of the kind have posed certain threat to the national economic security and the security of people's property.

Besides, as a system, virtual economy is highly instable in itself. Along with deepening of virtual economic globalization, the proportion of virtual economy in China keeps increasing. The compounding of the instability and the expanding scale undoubtedly poses a hidden danger to security and stability of the national economy. However, from another perspective, as a "mobile reserve pool," virtual economy can defend against various economic impacts, and can avoid the huge impact on the national economic environment caused by the international environmental changes. [4]

A. Countermeasures against risks of national economic security

1) Strengthen the country's management capability of virtual capitals

Even if virtual economic globalization is a future development trend, its development should conform to China's basic national situations. The ratio of virtual economy to real economy should be maintained at a proper level. Virtual economy should not be regarded as the only driving force of economic development.

Of course, the development trend of the world economy is a guideline for the national economic development. China should control the proportion of virtual economy, and accelerate its development as well. Despite of steady progress of China's virtual economy, there is still a far gap between China and developed countries. The supervision system should be enhanced on the one hand; on the other 
hand, the development speed should be guaranteed. Only in this way can quality virtual economic development be achieved.

Based on demands of these two aspects, China should enhance its management capability of virtual capitals through standardization of various financial market operation modes, enhancement of supervision and investigation of the virtual economic market, implementation of all-around supervision of external capitals and guarantee of virtual economic operation under the national supervision.

2) Build the virtual economic platform for RMB's internationalization

At present, RMB has shown its supporting role in the field of real economy. As the world's economic situations keep changing, development of virtual economy's currency policies is an issue of great concern to RMB's development. If the RMB wants to increase its degree of opening to the outside world, policy restrictions should be lifted. Before an all-around opening, the virtual economic platform for RMB's internationalization should be reliable and safe so as to enhance China's economic security.

\section{Conclusions}

To sum up, based on the research of China's virtual economic development status and demonstrations of the virtual economic globalization, the influence of the virtual economic globalization on China are pointed out, which is both negative and positive. In terms of its positive influence, China should avail itself of it to achieve greater development. In terms of negative influence, China should enhance its national economic security guarantee system so that virtual economy can find a sustainable and sound development path for it.

\section{References}

[1] SU Guohui. Study on China's economic security from the perspective of East Asian Economic Cooperation [D]. Liaoning University, 2011.

[2] ZHONG Chongwen. Research on influence of virtual economy on real economy [D]. Jilin University, 2011.

[3] WANG Qianqian. The influence of the financial globalization onto the financial safety of developing countries [D]. East China Normal University, 2005.

[4] FAN Yuanjie. Discussion on the issue of virtual economy globalization and national economic security [J]. Inner Mongolia Coal Economy, 2016, 09: 36+43. 